\title{
Do Macroeconomic Crises Always Slow Human Capital Accumulation?
}

\author{
Norbert R. Schady
}

\begin{abstract}
The impact of macroeconomic crises on the investments made by parents in the human capital of their children is a question of considerable policy importance. Analysis of the effects of the profound 1988-92 macroeconomic crisis in Peru on the schooling and employment decisions of school-age children in urban areas finds no effect on attendance rates but a significant decline in the fraction of children who are both employed and attend school. It also finds significantly higher mean educational attainment for children exposed to the crisis than for those who were not. These findings may be related: Children who are not employed have more time available and may therefore put more effort into school.
\end{abstract}

Normally Simon and I would have gone to work after high school, but jobs weren't to be had anyway, and the public college was full of students in our condition, because of the unemployment. - Saul Bellow, The Adventures of Augie March

How do macroeconomic crises affect the schooling and employment decisions of children and their parents? Do such crises invariably slow human capital accumulation, especially among the poor, thus transmitting poverty across generations? Policymakers in the developing world, as well as such international organizations as the United Nations Children's Fund and the World Bank, often worry that households that are unable to smooth consumption during a crisis may cut back on expenditures on the education, health, and nutrition of their children (World Bank 2001). This is plausible but not self-evident.

In the standard neoclassical model of human capital investment individuals acquire schooling until the (expected) marginal benefit of an additional year of

Norbert R. Schady is Senior Economist, Development Research Group at the World Bank; his e-mail address is nschady@worldbank.org. The author would like to thank Jean Boivin and Olivier Deschenes for many useful conversations and work on an earlier draft of this article and, for their comments, Harold Alderman, François Bourguignon, Francisco Ferreira, Cesar Guadalupe, Gillette Hall, Hanan Jacoby, José Rodríguez, Jaime Saavedra, Carolina Sánchez-Páramo, Miguel Urquiola, three anonymous referees, participants at the Latin American and Caribbean Economic Association Conference in Montevideo, Uruguay, on October 18-20, 2001, and participants at the Inter-American Development Bank conference on "Crises and Disasters: Measurement and Mitigation of their Human Costs" in Washington, D.C., on November 13-14, 2001. The author also thanks Gilberto Moncada at Peru's National Institute for Statistics and Informatics, Jaime Saavedra at the Development Analysis Group in Peru, and Moisés Ventocilla at Cuánto for help with the data.

THE WORLD BANK ECONOMIC REVIEW, VOL. 18, NO. 2,

(C) The International Bank for Reconstruction and Development / THE WORLD BANK 2004; all rights reserved. doi:10.1093/wber/lhh036

18:131-154 
education equals the marginal cost (Rosen 1977; Willis 1986). The marginal benefit of one more year of schooling is the resulting increase in the discounted expected stream of earnings and the marginal cost is the forgone income and such direct private costs as tuition and transportation. Borrowing constraints may be an additional cost of attending school by preventing consumption smoothing, especially by poor households (Becker 1964; Jacoby 1994 on Peru).

In general, an adverse macroeconomic shock will depress current employment and wage prospects, so the opportunity cost of attending school will fall. Holding everything else the same, this should lead to increased investments in human capital. But a shock could also make borrowing constraints more binding and thus reduce the total amount of schooling chosen.

When macroeconomic shocks are persistent, they may also depress expected lifetime earnings, thus affecting the marginal benefit from schooling. If the lifetime earnings of all individuals are reduced by the same percentage, regardless of their schooling, then the marginal benefit associated with an additional year of schooling will be lower (by this same percentage). But crises need not have a uniform across-the-board effect on expected earnings. For example, if the expected lifetime earnings for individuals with less education are disproportionately affected by the crisis, the marginal benefit to schooling could rise. Insofar as macroeconomic crises change the marginal costs of schooling, they may also affect the timing and intensity of schooling - in particular, the extent to which children combine schooling with part-time employment. Finally, the effect of a crisis on the wages and employment prospects of adults in a household may also have an effect on the schooling and employment decisions of children.

Thus the effect of a macroeconomic crisis on schooling is ambiguous in theory. Children (or their parents) may choose more or less schooling, they may anticipate or postpone further schooling, and they may expend more or less effort in school. The total effect of a crisis on schooling will depend on the relative magnitude of the changes in the marginal costs and benefits from education, as well as on the cross-price elasticity of child employment and adult wages.

Given such uncertain predictions, careful, country-specific empirical work is needed. Goldin (1999) finds a large increase in secondary school enrollment rates during the Great Depression in the United States, especially in the states hit hardest by unemployment. In Latin America, De Ferranti and others (2000) suggest that by and large enrollment decisions are unaffected by macroeconomic crises, especially moderate ones. More recent work on Argentina confirms that the crisis of the late 1990s and early 2000s did not change overall enrollment levels, but it may have had negative effects on the quality of schooling because of high associated rates of teacher absenteeism (España and others 2002). In Indonesia the deep financial crisis of 1998 appears to have had only very small effects on schooling outcomes (Strauss and others 2004; Thomas and others 2004). In rural India, Jacoby and Skoufias (1997) find that school attendance is responsive to seasonal fluctuations in income, although this does not appear to result in large losses of human capital, whereas Jensen (2000) shows large negative effects of rainfall shocks on school 
enrollment in Côte d'Ivoire. In sum, the effect of income shocks on schooling seems to vary considerably by country (as well as possibly by the nature of the crisis), with the largest effects being found in the poorest countries. ${ }^{1}$

This article analyzes the effects of the 1988-92 economic crisis in Peru on school attendance, employment, and years of schooling completed. The analysis finds no evidence that school attendance fell during the crisis, either overall or for specific population groups, such as the poor. Overall attendance was stable, and the proportion of children who combined school with work declined significantly during the crisis. The number of grades completed for a given age was higher for children exposed to the crisis and increased with the number of years of crisis exposure.

\section{The Peruvian Setting}

The Peruvian case is well suited to a study of the impact of macroeconomic crises on schooling outcomes for several reasons. First, the crisis in Peru was particularly deep and prolonged. National accounts data suggest that gross domestic product (GDP) per capita fell almost 30 percent between 1988 and 1992. The depth and duration of the crisis could have severely stretched the ability of households to protect investments in schooling. Second, reliable household data are available. Three Living Standards Measurement Study (LSMS) surveys cover the period before (1985/86), during (1991), and after (1997) the crisis. These surveys provide detailed information on household characteristics, such as demographic structure, income, consumption, access to credit, parental education, and child outcomes, including educational attainment and employment.

\section{Economic Developments, 1985-97}

Peru followed an erratic economic course in the 1980s and 1990s. Between 1985 and 1990 the government of Alan García attempted to stimulate the economy with a heterodox stabilization program, relying on reduced foreign debt payments, a price freeze, and economic stimulus through wage increases, job creation programs, and increased investments in education and health. These policies encouraged high growth rates in 1986 and 1987, but the inflationary pressures and budget deficits quickly proved unsustainable (Glewwe and Hall 1994). The country slid into a deep recession and hyperinflation in 1988. By the end of García's term in 1990, the economy was in a state of near collapse: GDP per capita had fallen 10.5 percent in 1988, 13.4 percent in 1989, and 6.9 percent in 1990, and inflation had soared to 667 percent, 3,399 percent, and 7,482 percent (figure 1). Along with the economic crisis came a deterioration in public safety. By 1990 there was virtual

1. Other studies have considered the impact of macroeconomic volatility-although not macroeconomic crises per se-on schooling outcomes. Using cross-country regressions, Flug and others (1998) report that income and employment volatility have negative effects on secondary school enrollment in Latin America. Behrman and others (2000) suggest that the low (or negative) growth rates in the 1980s in Latin America set back the rate of growth of schooling attainment in the region. 
Figure 1. Real per capita GDP and Inflation in Peru, 1980-99

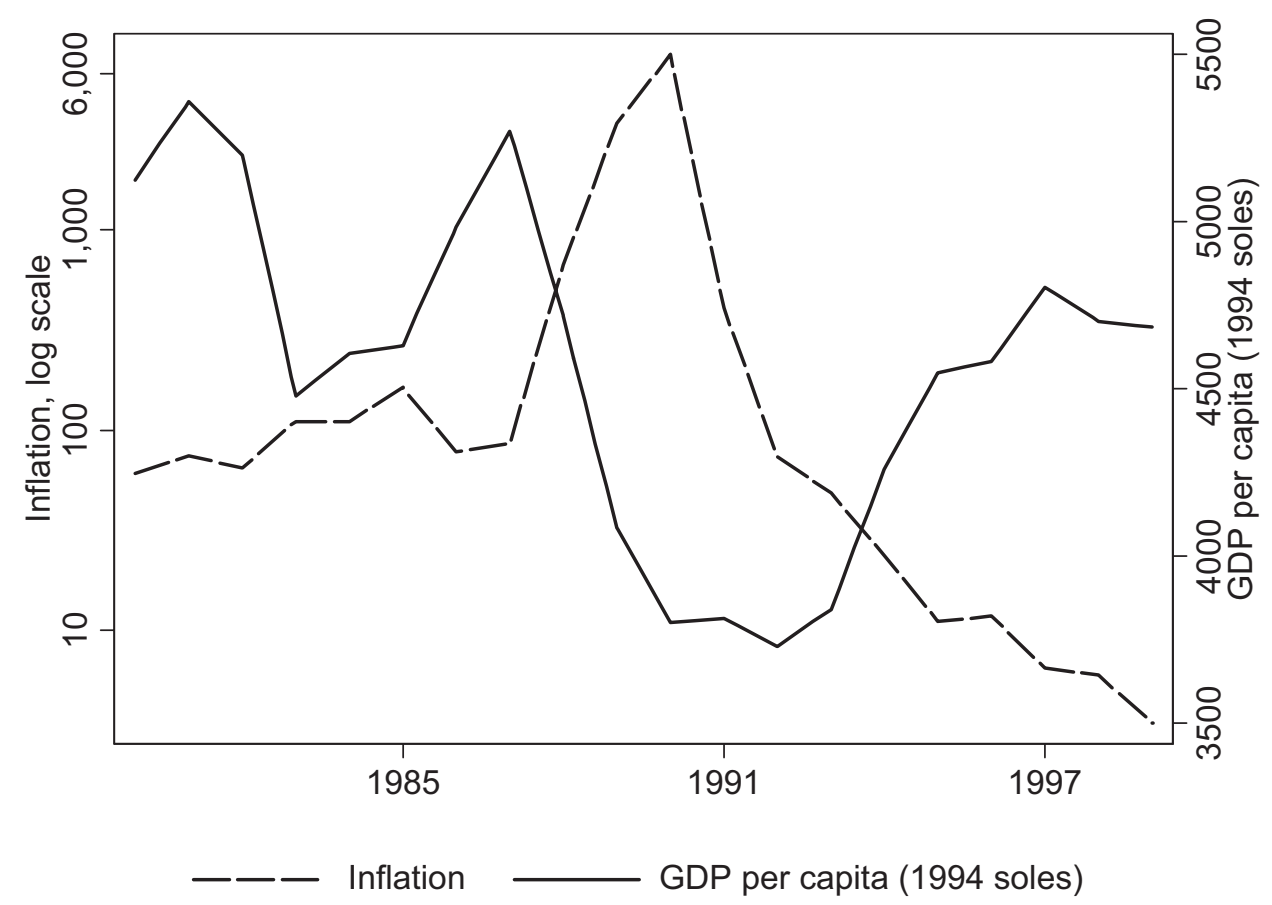

Source: World Bank data.

civil war between the armed forces and the insurgents of the Shining Path and Túpac Amaru Revolutionary Movement in some areas of the country.

The administration of Alberto Fujimori, who took office in 1990, opted for more orthodox economic remedies. Reforms included elimination of controls on prices, interest rates, and foreign exchange transactions; tariff reductions; labor market deregulation; and a far-reaching program of privatization. Growth picked up after 1992, inflation fell to 74 percent in 1992 and to less than 12 percent by 1995 (see figure 1), and poverty declined. Like the crisis, the recovery appears to have been far reaching, affecting all regions and most households (World Bank 1995, 1999a). ${ }^{2}$ Meanwhile, order was gradually reestablished in the countryside, in particular after the 1992 capture of Abimael Guzmán, leader of the Shining Path.

\section{Education in Peru, 1985-97}

Compared with many of its Latin American neighbors and other countries with similar income levels, Peru has attained impressively high enrollment rates in both primary and secondary school. Analysis of the 1997 LSMS survey suggests that 97.5 percent of 6-11-year-olds, 86.3 percent of 12-17-year-olds, and

2. Strict comparisons of poverty measures are not possible because of differences in the coverage of the surveys (see section II). 
34.9 percent of $18-25$-year-olds were attending some educational institution. ${ }^{3}$ These figures are particularly impressive because of the low levels of public spending on education. In 1997 total public spending on education in Peru was 3 percent of GDP (2.4 percent net of spending on pensions), compared with the Latin American average of 4.5 percent (World Bank 1999b).

In contrast, private expenditures on education in Peru, at about 2 percent of GDP, are high and well above the average of 1.3 percent for Organisation for Economic Co-operation and Develoment member countries. As in other countries, private expenditures vary by education levels and income quintile. In 1997 households spent about three times as much to send an 18-25-year-old to school as to send a 6-11-year-old. Differences across income quintiles are starker. On average, households in the richest income quintile spent about eight times as much for children ages 6-11 attending school as did households in the poorest income quintile, five times as much for children $12-17$, and four times as much for children 18-25.

\section{Data And Sample Means}

The main sources of data for this analysis are the 1985/86, 1991, and 1997 Peru LSMS surveys. These surveys contain information on household characteristics, school attendance, grade attainment, and labor force participation.

The questions in all three surveys are generally comparable, ${ }^{5}$ but coverage of the surveys is not comparable across years. Although the 1985/86 and 1997 surveys visited households in each one of Peru's seven "natural regions"-Lima, the urban and rural areas of the coast, sierra (or highlands), and selva (or jungle)—the 1991 survey sampled households only in Lima, the urban coast, and the urban and rural areas of the sierra.

There are also reasons for concern about the 1991 sample for the rural sierra. Mean income appears to be higher in 1991 than in 1997, and parents' mean years of education approximately doubles between 1985/86 and 1991 and stays constant thereafter (table 1). It is likely that inadequate funding for the 1991 survey or the dangerous conditions caused by widespread terrorism in the rural

3. Author's calculations based on the 1997 LSMS survey tapes. These numbers cover all seven regions in Peru, including rural areas and the urban areas of the selva and so do not correspond to the numbers in tables 2 and 3, which cover only Lima and the urban areas of the coast and sierra. Figures for school attendance for 6-14-year-olds can also be calculated from the 1996 Peru Demographic and Health Survey (Filmer 1999). These tend to be quite similar, except for 6-year-olds, whose attendance rates in the Demographic and Health Survey (61.3 percent) appear to be much lower than those from the LSMS surveys, likely a result of differences in the wording of the question.

4. Still, by international standards, these differences in expenditure patterns across income quintiles are modest. As a comparison, in the Philippines households in the richest quintile spend 20 times as much as households in the poorest quintile per student in primary school, 11 times as much per student in secondary school, and 11 times as much per student at the tertiary level (Schady 2001, p. 34).

5. There are some exceptions. For example, there are differences across surveys in the recall periods and in the level of disaggregation in the questions concerning household expenditures on education. 


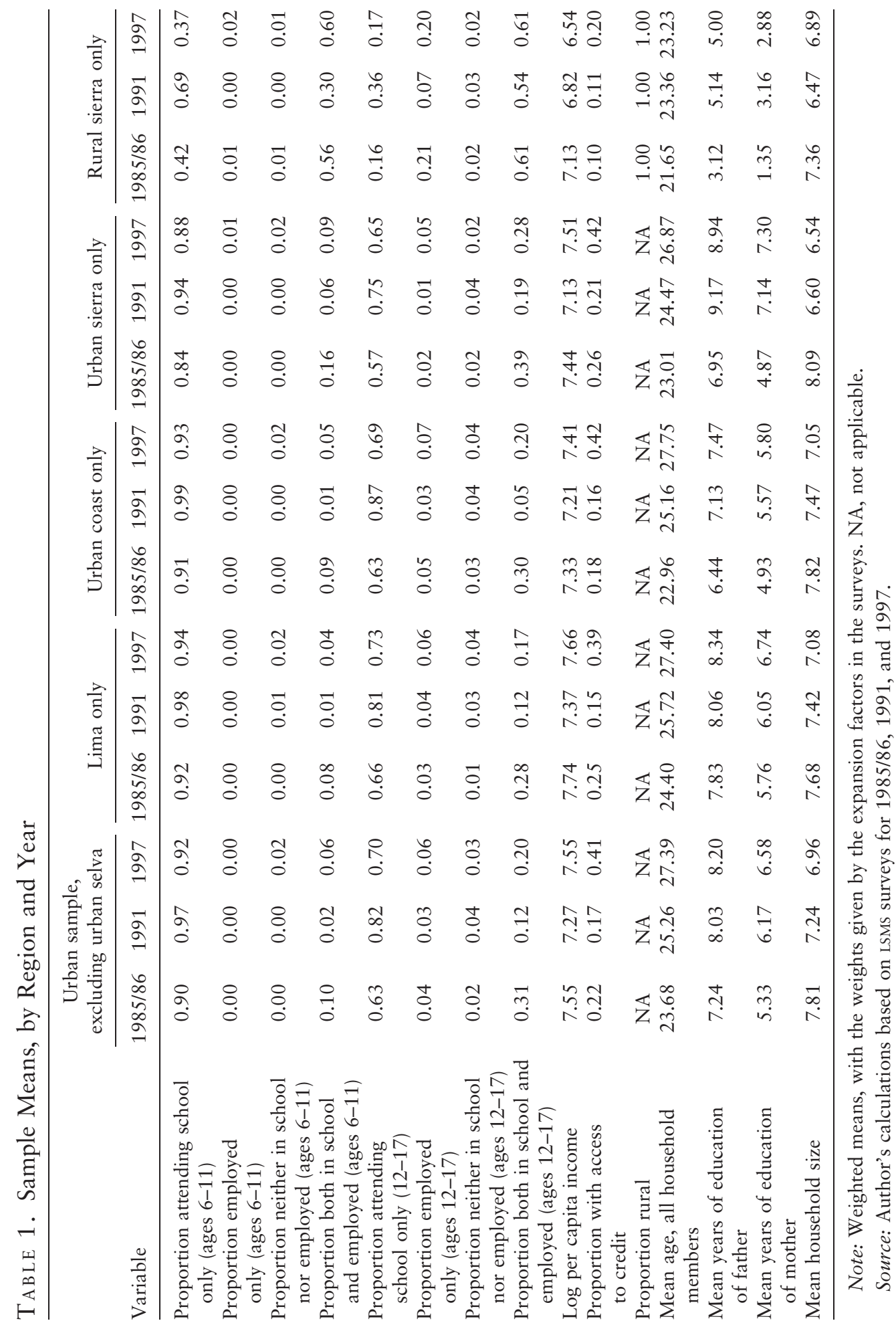


sierra in the early 1990s prevented enumerators from visiting outlying, poorer, less well-educated households. The sample for the analysis is therefore limited to Lima and the urban areas of the coast and sierra. In 1997 these three regions jointly accounted for about 58.1 percent of the population. Regressions were also run with samples that included the rural sierra. In all these results, which are available on request, the impact of the crisis was larger in absolute value than the impacts reported for the urban sample.

\section{Construction of Variables}

The analysis considers the impact of the 1988-92 crisis on three outcomes: school attendance, mean number of grades completed, and employment. Attendance is based on answers to two questions in the surveys. All household members age 6 and older are asked whether they are "currently attending school or studying something." Those who answer "no" are then asked whether they "attended school or studied something in the last 12 months." 6 The variable constructed for attendance takes a value of one for all individuals who answer "yes" to either of these questions. Because a large share of households in the 1985/86 survey were questioned during the summer vacation months of December-March, attendance rates based on only the first question would be unreasonably low. The 1991 and 1997 surveys were both conducted between September and November. ${ }^{7}$ A variable was also constructed for the total number of grades a child has completed.

The measure of employment is based on questions asked of all household members ages six and older. These questions first ask respondents whether they worked "as an employee for a business, corporation, government, a boss, or another individual" and second whether they worked "for themselves [a cuenta propia] or as an unpaid family member," or "on the [family] farm." The reference period for both questions is the past week. Follow-up questions with longer reference periods (12 months) are asked of those who answered that they did not work in the last week. All those who answer affirmatively to any of the four questions are considered to have been employed. ${ }^{8}$

6. This measure of attendance does not take into account the number of times children actually go to school-a shortcoming of the data. Using the term enrollment would also be somewhat inaccurate, however, because children may be formally enrolled in school but not attend. The Spanish word used in the survey questions (asistir al colegio) is closer to attendance than it is to enrollment (the translation for enrollment would be estar inscrito o matriculado en el colegio). See Paxson and Schady (2002) for a similar construction of variables.

7. Insofar as differences in the timing of the surveys make comparisons of school attendance (or employment-see later discussion) across years more problematic, even after taking into account both attendance questions in the LSMS surveys, this should not affect comparisons between 1991 and 1997.

8. In the 1985/86 and 1991 surveys working "on the farm" and working "for themselves, or as an unpaid family member" are asked separately, whereas in the 1997 survey both options are listed as part of the same question. Household chores are meant to be excluded from these categories and are asked about in the following questions. 
The Peruvian think-tank the Development Analysis Group (GRADE) has calculated comparable consumption and income aggregates for the 1985/86, 1991, and 1997 LSMS surveys as well as for a 1994 LSMS survey. It used 1997 price deflators to adjust for price differences across natural regions, and the national consumer price index to deflate consumption and income over time. GRADE's income aggregates are used for the estimations in this study, with the exception of the 1994 survey because GRADE's aggregates for that year suggest that mean income was lower in 1994 than in 1991, whereas the national accounts show a clear improvement during this period. It is therefore unclear whether 1994 should be treated as a crisis year. ${ }^{9}$ The 1994 data are included in some (unreported) regressions, however, and the results suggest that there are no significant differences in school attendance and employment patterns between 1991 and 1994.

Some of the results reported here use a measure of crisis "exposure" as an explanatory variable. Years of exposure are determined by the number of years a child was between the ages of 6 and 17 during 1988-92. All school-age children surveyed in 1985/86 were unexposed to the crisis, and all school-age children surveyed in 1991 were exposed to the crisis (with the extent of exposure determined by their age). For school-age children surveyed in 1997 exposure depends on age; those ages 11-17 were exposed to the crisis during their schoolage years, whereas those ages 6-10 were not. Overall, then, the range of this exposure variable is between zero for children who were never of school age during the crisis and five for children who were of school age during every year between 1988 and 1992 (see appendix table A1). ${ }^{10}$

\section{Sample Means}

The 1988-92 crisis affected all regions and all income quintiles (tables 1 and 2). Income dropped across the board, and credit became harder to come by. Only 17 percent of households report having had access to credit in 1991 compared with 22 percent in 1985/86 and 41 percent in 1997. Tables 1 and 2 also show expected secular trends in parental education (rising), age (rising), and household size (falling).

Children (or their parents) make decisions about schooling and employment jointly and sort themselves into one of four mutually exclusive categories: attend school only, work only, neither attend school nor work, and both attend school and work. The means for these four categories are shown by survey year for the full urban sample (excluding the urban selva, which was not included in the 1991 survey) and for each geographic stratum separately (see table 1) and by gender and by poorest and richest income quintiles for the full urban sample (see table 2).

Results on attendance and employment patterns are presented separately for children ages 6-11, corresponding roughly to primary school age, and ages 12-17,

9. See Deaton (2003) and Ravallion (2003) for possible explanations of such divergences between the survey and national accounts figures.

10. For the age calculations all children surveyed in $1985 / 86$ are taken to have been surveyed in 1985 , given that the majority of households were surveyed in 1985 rather than 1986. 


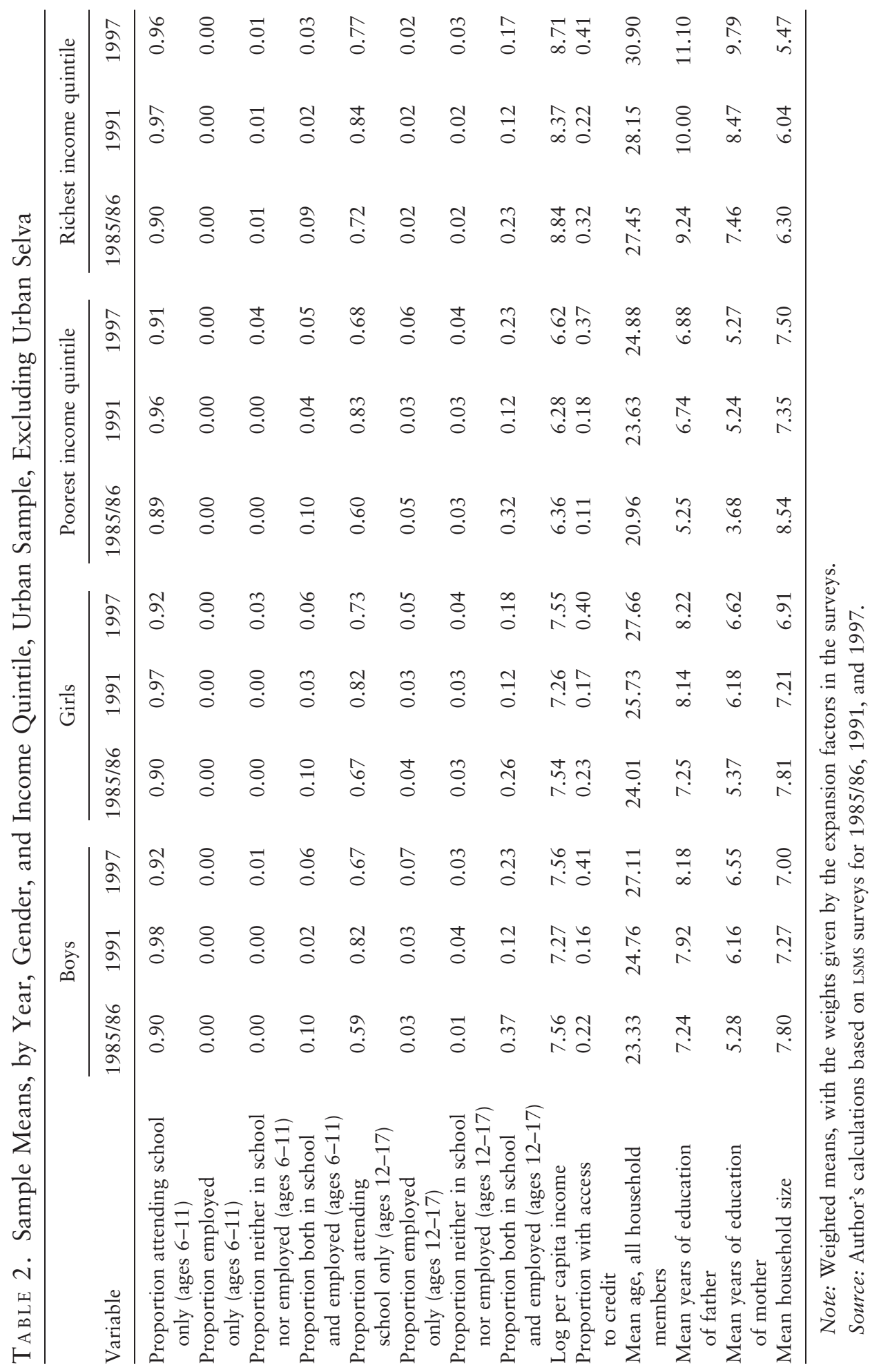


corresponding roughly to secondary school age. Attendance levels for schoolage children in urban areas are very high throughout, at 97 percent or higher for children ages 6-11 and 90 percent or higher for children ages 12-17 (see tables 1 and 2). By and large, most children go to school in urban Peru, and there is no indication that attendance levels were lower in the 1991 crisis year.

But the extent to which children combine school and work changed dramatically across years. The fraction of children who were working is consistently lower in 1991 than in 1985/86 or 1997. Differences are particularly large for older children. In the full urban sample, 31 percent and 20 percent of children ages 12-17 were both attending school and employed in 1985/86 and 1997, respectively. In 1991, by contrast, only 12 percent of children in this age group combined school and work. This pattern holds remarkably consistently across strata, for girls as well as boys, and for children in the richest and poorest income quintiles.

Charting the mean number of grades passed by age for children exposed and unexposed to the crisis, without conditioning on attendance, shows that mean years of schooling are below the ideal on-track progression line. This is especially clear at higher ages, because of dropouts and the cumulative effects of late school entry and repetition (figure 2). However, children exposed to the crisis have an average of 0.1-0.2 more years of schooling. There is no clear pattern whereby children unexposed to the crisis fall further behind or catch up with age.

\section{Econometric Specification and Results}

To control for changes in household characteristics across survey years, data from the three surveys are pooled to estimate probit regressions for contemporaneous events - the probability of attending school or being employed. These regressions include dummy variables for the two noncrisis survey years (1985/86 and 1997) and other controls. The omitted category is therefore the crisis year of 1991 . The changes in the probability associated with the 1985/86 and 1997 dummy variables are interpreted as year effects conditional on changes over time in household characteristics. Pervasive, predictable differences across years could be consistent with a causal effect of the 1988-92 crisis on attendance and employment.

The second part of the analysis reports the results of ordinary least squares (oLs) regressions in which the dependent variable is cumulative-the number of grades passed for age. These regressions include dummy variables for two survey years, as well as the measure of crisis exposure. The coefficients on the measure of exposure are interpreted as the marginal effect of a year of exposure to the crisis on the number of grades passed.

For both parts of the analysis, specification (1) includes dummy variables for survey year, geographic stratum, gender, and a set of age dummy variables. The oLs regressions also include the measure of crisis exposure. Information on years 
Figure 2. Number of Grades Completed, by Age

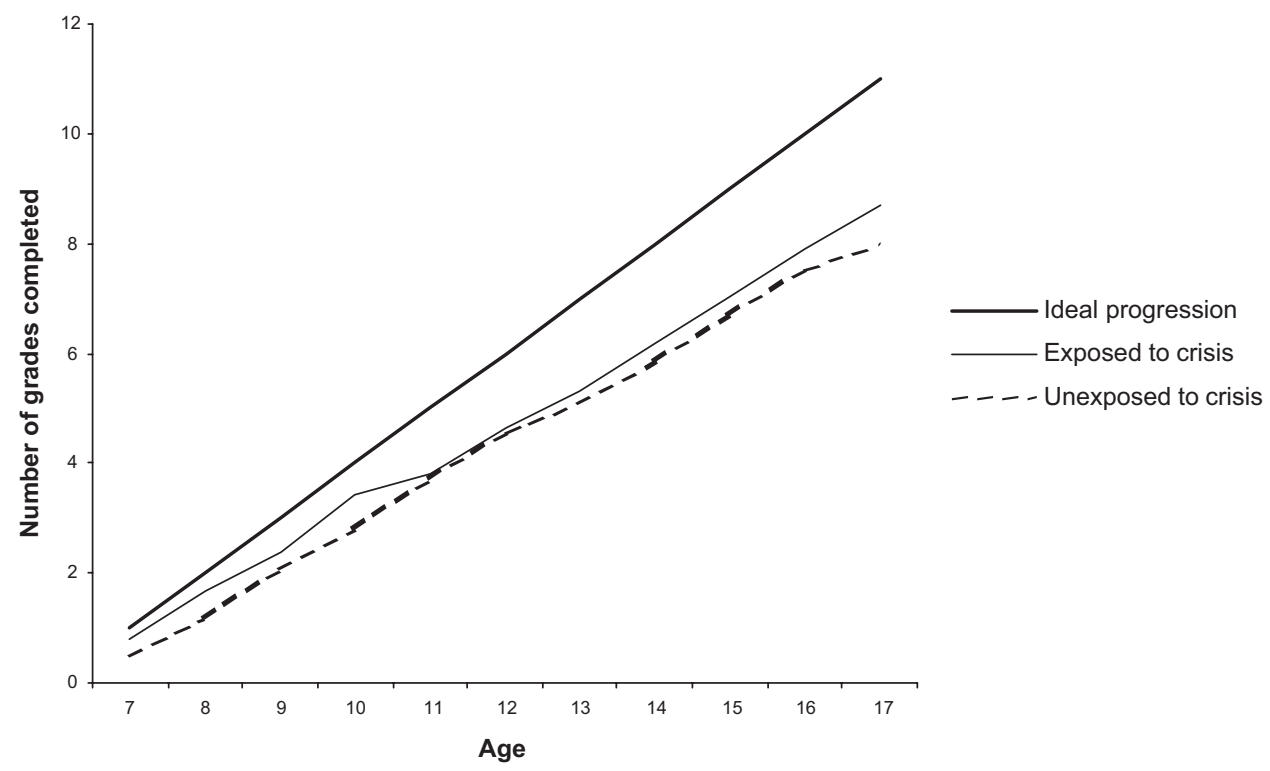

Note: Children are expected to start first grade at age 6 or 7 . Therefore they should have passed first grade by age 8 , second grade by age 9 , and so on, unless they start school late or repeat a grade. Children are considered to be on track if they have completed at least this number of grades for their age, a generous definition because children who start school at age 6 should have completed first grade by age 7 .

Source: Author's calculations based on the LSMS surveys for 1985/86, 1991, and 1997.

of education of both parents (separately) is available for a subsample of children-those who live in households in which both parents are present and who are the sons or daughters of the household head. Specification (2) therefore adds controls for the education of both parents (separately), dummy variables for the age structure within the household, and a main effect in household size.

The LSMS survey data include identifiers for mapping households in the surveys to the districts in which they live. ${ }^{11}$ The fixed effects specifications in (3) limit the analysis to households living in districts that were included in the sample in 1985/86, 1991, and 1997 and include the variables in specification (2), as well as dummy variables for each district. These regressions therefore identify differences in attendance levels, employment levels, and educational attainment from within-district variation across survey years or birth cohorts.

11. Peru has more than 1,800 districts, which are the smallest political and administrative division in the country (roughly comparable to counties in the United States). According to the 1993 population census, average district population was 12,600 inhabitants. Some predominantly rural districts have fewer than 200 inhabitants, whereas a handful of urban districts in Lima have more than 100,000 inhabitants (Schady 2002, p. 419). 
(Note that district fixed effects are not a satisfactory solution for the problem of differences in the sample in the rural sierra between the 1985/86 and 1997 surveys and the 1991 survey. The likely problem with the 1991 sample for the rural sierra is not that enumerators did not visit outlying districts but that they did not visit outlying areas within a given district.)

One disadvantage of the estimations that include measures of parental education and those with district fixed effects is that both are limited to subsamples of the data. In the three regions considered in the analysis, data on the schooling of both parents are available only for 73.9 percent of 6-11-year-olds, and only 77.8 percent of 6-11-year-olds live in districts that were included in the samples in 1985/86, 1991, and 1997. The sample sizes for the within-district regressions are further reduced when all children in a district have the same outcome-for example, if all children ages 6-11 in a district attend school or if none of them is employed. Better controls therefore come at the cost of smaller sample sizes and less precision.

\section{Attendance and Employment}

For children ages 6-11 and for those ages 12-17 the probability of attending school is significantly lower in 1997 than in 1991, but not in 1985/86 (table 3).

Table 3. Probability of Attending School

\begin{tabular}{lccc}
\hline & Specification $(1)^{\mathrm{a}}$ & Specification $(2)^{\mathrm{b}}$ & ${\text { Specification }(3)^{\mathrm{c}}}^{\text {Children ages 6-11 }}$ \\
\hline $1985 / 86$ & 0.000 & -0.000 & 0.000 \\
1991 & $-0.016^{* * *}$ & $-0.012^{* * * *}$ & - \\
1997 & 0.12 & 0.29 & $-0.019^{* * *}$ \\
Pseudo $R^{2}$ & 3,257 & 2,573 & 0.44 \\
Number of observations & & & 845 \\
Children ages 12-17 & 0.002 & 0.001 & $0.002^{* *}$ \\
$1985 / 86$ & - & - & - \\
1991 & $-0.017^{* *}$ & $-0.003^{* *}$ & $-0.002^{* *}$ \\
1997 & 0.17 & 0.26 & 0.30 \\
Pseudo $R^{2}$ & 4,393 & 3,092 & 2,130 \\
Number of observations & &
\end{tabular}

Note: The dependent variable takes a value of one if a child is attending school and zero otherwise. The table reports changes in the probability of attending school at the means of other variables. Standard errors are corrected for heteroskedasticity and clustering.

**Significant at the 5 percent level.

$* *$ Significant at the 1 percent level.

${ }^{a}$ Includes geographic stratum and gender controls and a vector of age dummy variables.

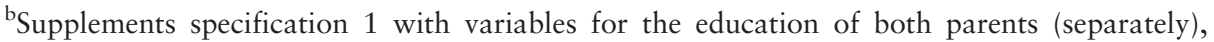
household size, the number of household members under age 3, ages 3-5, ages 6-8, ages 9-11, ages 12-14, and ages 15-17.

${ }^{\mathrm{c}}$ This fixed effects specification limits the sample to households living in districts that were included in the sample in 1985/86, 1991, and 1997, and includes the variables in specification 2, as well as a dummy variable for each district.

Source: Author's calculations based on LSMS surveys for 1985/86, 1991, and 1997. 
Table 4. Probability of Being Employed

\begin{tabular}{lccc}
\hline & Specification $(1)^{\mathrm{a}}$ & Specification $(2)^{\mathrm{b}}$ & Specification $(3)^{\mathrm{c}}$ \\
\hline Children ages 6-11 & $0.089^{* * *}$ & $0.082^{* * *}$ & $0.054^{* * *}$ \\
$1985 / 86$ & - & - & - \\
1991 & $0.056^{* * *}$ & $0.078^{* * *}$ & $0.042^{* *}$ \\
1997 & 0.10 & 0.13 & 0.15 \\
Pseudo $R^{2}$ & 4,322 & 3,160 & 2,234 \\
Number of observations & & & \\
Children ages 12-17 & $0.223^{* * *}$ & $0.161^{* * *}$ & $0.168^{* * *}$ \\
$1985 / 86$ & - & - & $-157^{* *}$ \\
1991 & $0.138^{* * *}$ & 0.11 & $0.144^{* * *}$ \\
1997 & 0.07 & 3,100 & 0.14 \\
Pseudo $R^{2}$ & 4,405 & 2,253 \\
Number of observations &
\end{tabular}

Note: The dependent variable takes on a value of one if a child is employed and zero otherwise. The table reports changes in the probability of being employed at the means of other variables. Children are considered to be employed if they responded affirmatively to any of the following questions in the surveys: (1) "In the last 7 days, did you work as an employee for a business, corporation, government, a boss, or another individual?"; (2) "and in the last 12 months?"; (3) "In the last 7 days, did you work for yourself, [a cuenta propia, or self-employed], or as an unpaid family member, or on the farm?"; (4) "and in the last 12 months?" Standard errors are corrected for heteroscedasticity and clustering.

* Significant at the 5 percent level.

$* *$ Significant at the 1 percent level.

ancludes geographic stratum and gender controls and a vector of age dummy variables.

${ }^{\mathrm{b}}$ Supplements specification 1 with variables for the education of both parents (separately), household size, the number of household members under age 3 , ages $3-5$, ages $6-8$, ages $9-11$, ages $12-14$, and ages $15-17$.

'This fixed effects specification limits the sample to households living in districts that were included in the sample in 1985/86, 1991, and 1997, and includes the variables in specification 2, as well as a dummy variable for each district.

Source: Author's calculations based on LSMS surveys for 1985/86, 1991, and 1997.

But the differences are small—the probability of attending school is, at most, 2 percentage points lower in 1997 than in $1991 .^{12}$

Differences in the probability of being employed are much larger than differences in the probability of attending school. On average a child age 6-11 was 4-9 percentage points more likely to be employed in either $1985 / 96$ or 1997 than in 1991, and a child age 12-17 was 14-22 percentage points more likely (table 4). All of these effects are significant at the 1 percent level or higher.

Looking at these results together suggests that the margin for adjustment in urban Peru is primarily in the extent to which children combine school and employment rather than in the extent to which they attend school. Results of

12. Note that children ages $12-17$ in 1997 were actually exposed to the crisis. If the crisis compelled some of these children to leave school, they might not have returned to school thereafter. The comparison of the dummy variables for 1991 and 1997 is therefore less persuasive for this older group than for the children ages 6-11. An anonymous referee provided this insight. 
regressions on differences across years in the probability that a child attends school and works relative to the probability that a child only attends school are very similar to those for differences in the probability of being employed because of the very high attendance rates (table 5). Children were much more likely to combine school and work in 1985/86 and 1997 than in the crisis year of 1991. (The results from multinomial regressions, unreported but available on request, show no significant differences across years in either the odds that children are employed only or in the odds that they are neither attending school nor employed. The only exception is in the odds of working only for 12-17year-olds relative to attending school and working, which is significantly higher in 1997 than in 1991.)

The regression results reported in tables 4 and 5 show a clear pattern of lower probabilities of child employment in 1991. The analysis then considers the kind of work children are doing-wage or nonwage employment. For children ages 6-11 the reduction in employment was almost exclusively a reduction in nonwage employment (table 6). For children ages 12-17 the picture is mixed. The proportion of children in both wage and nonwage employment was lower in 1991 than in either $1985 / 86$ or 1997 , although the bulk of the adjustment also

Table 5. Probability of Both Attending School and Being Employed

\begin{tabular}{lccc}
\hline & Specification $(1)^{\mathrm{a}}$ & Specification $(2)^{\mathrm{b}}$ & ${\text { Specification }(3)^{\mathrm{c}}}^{\mathrm{c}}$ \\
\hline Children ages 6-11 & $0.084^{* * *}$ & $0.078^{* * *}$ & $0.054^{* * *}$ \\
$1985 / 86$ & - & - & - \\
1991 & $0.054^{* * *}$ & $0.076^{* * *}$ & $0.040^{* *}$ \\
1997 & 0.09 & 0.12 & 0.16 \\
Pseudo $R^{2}$ & 4,220 & 3,086 & 2,193 \\
Number of observations & & $0.162^{* * *}$ & $0.168^{* * *}$ \\
Children ages 12-17 & $0.223^{* * *}$ & - & - \\
$1985 / 86$ & - & $0.150^{* * *}$ & $0.137^{* * *}$ \\
1991 & $0.133^{* * *}$ & 0.11 & 0.14 \\
1997 & 0.07 & 2,939 & 2,135 \\
Pseudo $R^{2}$ & 4,113 & & \\
Number of observations & &
\end{tabular}

Note: The dependent variable takes on a value of one if a child is both attending school and employed and zero if she is in school only. The table reports changes in the probability of both attending school and being employed at the means of other variables. Standard errors are corrected for heteroscedasticity and clustering.

**Significant at the 5 percent level.

$* *$ Significant at the 1 percent level.

${ }^{a}$ Includes geographic stratum and gender controls and a vector of age dummy variables.

${ }^{b}$ Supplements specification 1 with variables for the education of both parents (separately), household size, the number of household members under age 3, ages 3-5, ages 6-8, ages 9-11, ages $12-14$, and ages $15-17$.

${ }^{\mathrm{c}}$ This fixed effects specification limits the sample to households living in districts that were included in the sample in 1985/86, 1991, and 1997, and includes the variables in specification 2, as well as a dummy variable for each district.

Source: Author's calculations based on LSMS surveys for 1985/86, 1991, and 1997. 
Table 6. Sample Means for Schooling and Employment Status, by Type of Employment

\begin{tabular}{lrrr}
\hline & $1985 / 86$ & 1991 & 1997 \\
\hline Children ages 6-11 & & & \\
Attending school and no employment & 89.8 & 97.3 & 92.2 \\
Attending school and wage employment only & 0.7 & 0.5 & 1.0 \\
Attending school and nonwage employment only & 8.9 & 1.8 & 4.7 \\
Attending school and both wage and & 0.2 & 0.0 & 0.1 \\
$\quad$ nonwage employment & & & \\
Not attending school and no employment & 0.2 & 0.3 & 2.0 \\
Not attending school and wage employment only & 0.0 & 0.0 & 0.0 \\
Not attending school and nonwage employment only & 0.1 & 0.0 & 0.1 \\
Not attending school and both wage and & 0.0 & 0.0 & 0.0 \\
$\quad$ nonwage employment & & & \\
Total & 100.0 & 100.0 & 100.0 \\
Children ages 12-17 & & & \\
Attending school and no employment & 63.0 & 81.7 & 70.1 \\
Attending school and wage employment only & 7.5 & 2.8 & 5.9 \\
Attending school and nonwage employment only & 21.4 & 8.8 & 13.6 \\
Attending school and both wage and & 2.6 & 0.1 & 1.0 \\
$\quad$ nonwage employment & & & \\
Not attending school and no employment & 1.9 & 3.5 & 3.4 \\
Not attending school and wage employment only & 1.3 & 1.8 & 3.8 \\
Not attending school and nonwage employment only & 1.7 & 1.1 & 1.8 \\
Not attending school and both wage and & 0.6 & 0.2 & 0.3 \\
$\quad$ nonwage employment & & & \\
Total & 100.0 & 100.0 & 100.0 \\
\hline$\quad$ No: Weight & & &
\end{tabular}

Note: Weighted means, with the weights given by the expansion factors in the surveys.

Source: Author's calculations based on LSMS surveys for 1985/86, 1991, and 1997.

took place in nonwage employment. The poor aggregate conditions in 1991 may have lowered demand for child employment in the nonwage sector either because of lower demand for goods and services produced by home enterprises, which frequently employ children without remuneration, or because older workers lost their wage-paying jobs and displaced children from their nonwage jobs-or both.

Poorer households are more likely to be credit-constrained than are their better-off counterparts. Although the means in table 2 show no clear differences in outcomes between the first and fifth income quintiles, the regression coefficients reported in tables 3-5 might not hold for all income levels. To investigate this possibility, nonparametric (lowess) regressions are run of the probability of being both employed and in school on predicted log per capita annual household income (based on variables for age, gender, education of the household head, and household size and composition). (Predicted income is used because of the potential endogeneity of income in a child employment regression, but the results are very similar using actual income.) The 
Figure 3. Probability of Both Attending School and Being Employed for Children Ages 6-11, by Year

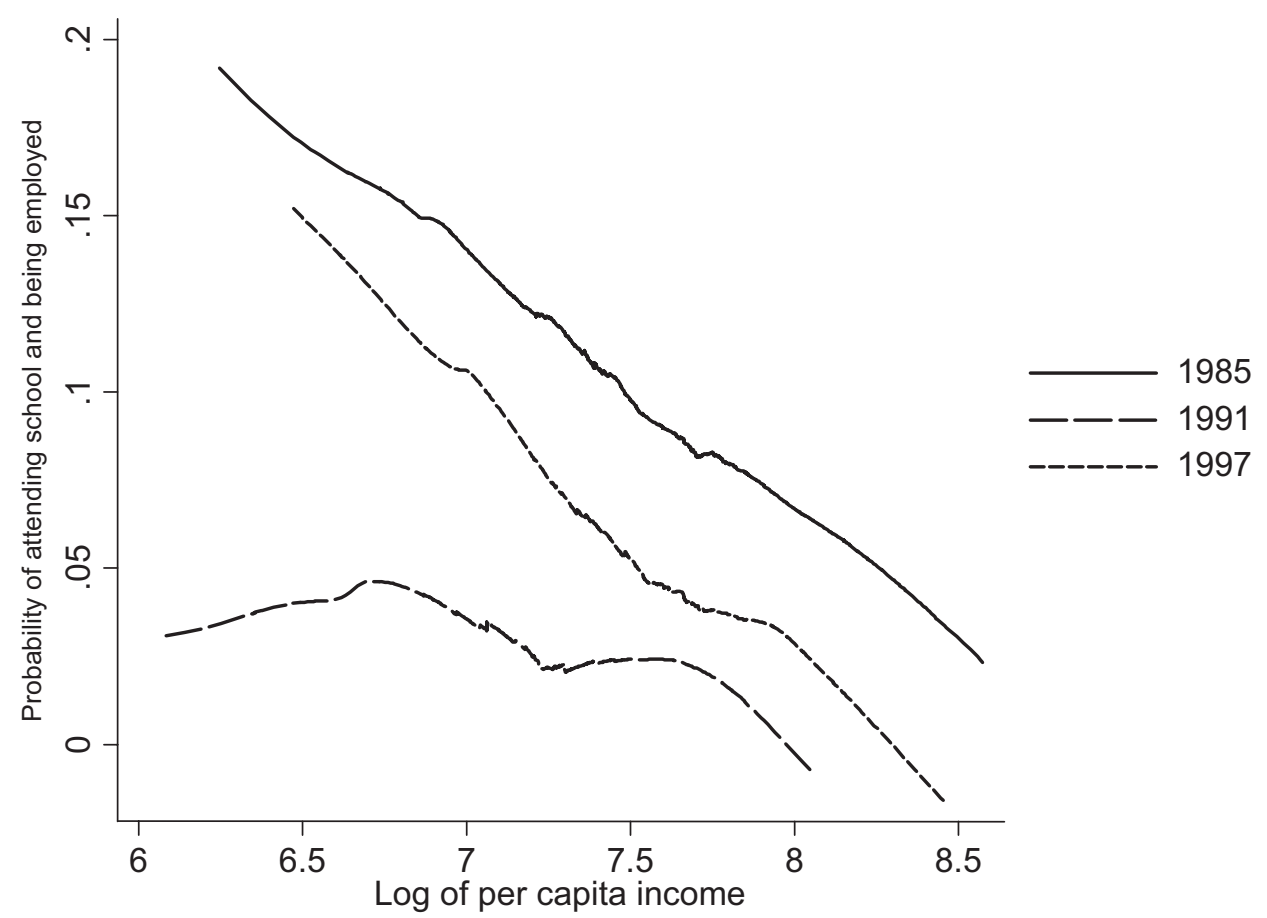

Source: Author's calculations based on the LSMS surveys for 1985/86, 1991, and 1997.

probability of being both in school and employed is lower in 1991 than in 1985/86 and 1997 across the entire income distribution (figures 3 and 4). ${ }^{13}$ The regression line is flattest in 1991, suggesting that the employment constraint may have been most binding for the poor. Still, the evidence for different responses to the crisis is limited. Additional (unreported) specifications test for heterogeneity in the year effects by interacting the year dummy variables with a number of household characteristics, such as the education of parents, household size, the dummy variables for geographic stratum, and the gender of the child. The coefficients on these interaction terms are insignificant, so we cannot rule out the null hypothesis of identical household responses to the crisis. Finally, the difference in slopes across years is most pronounced for children ages 6-11. Plausibly, jobs previously held by 6-11year-olds were taken by $12-17$-year-olds during the crisis, when jobs were scarce. ${ }^{14}$

13. Comparable graphs for the fraction of children who are attending school only, essentially the complement of the graphs in figures 3 and 4, show that the fraction of children who are attending school only is highest in 1991 at all income levels.

14. An anonymous referee provided this insight. 
Figure 4. Probability of Both Attending School and Being Employed for Children Ages 12-17, by Year

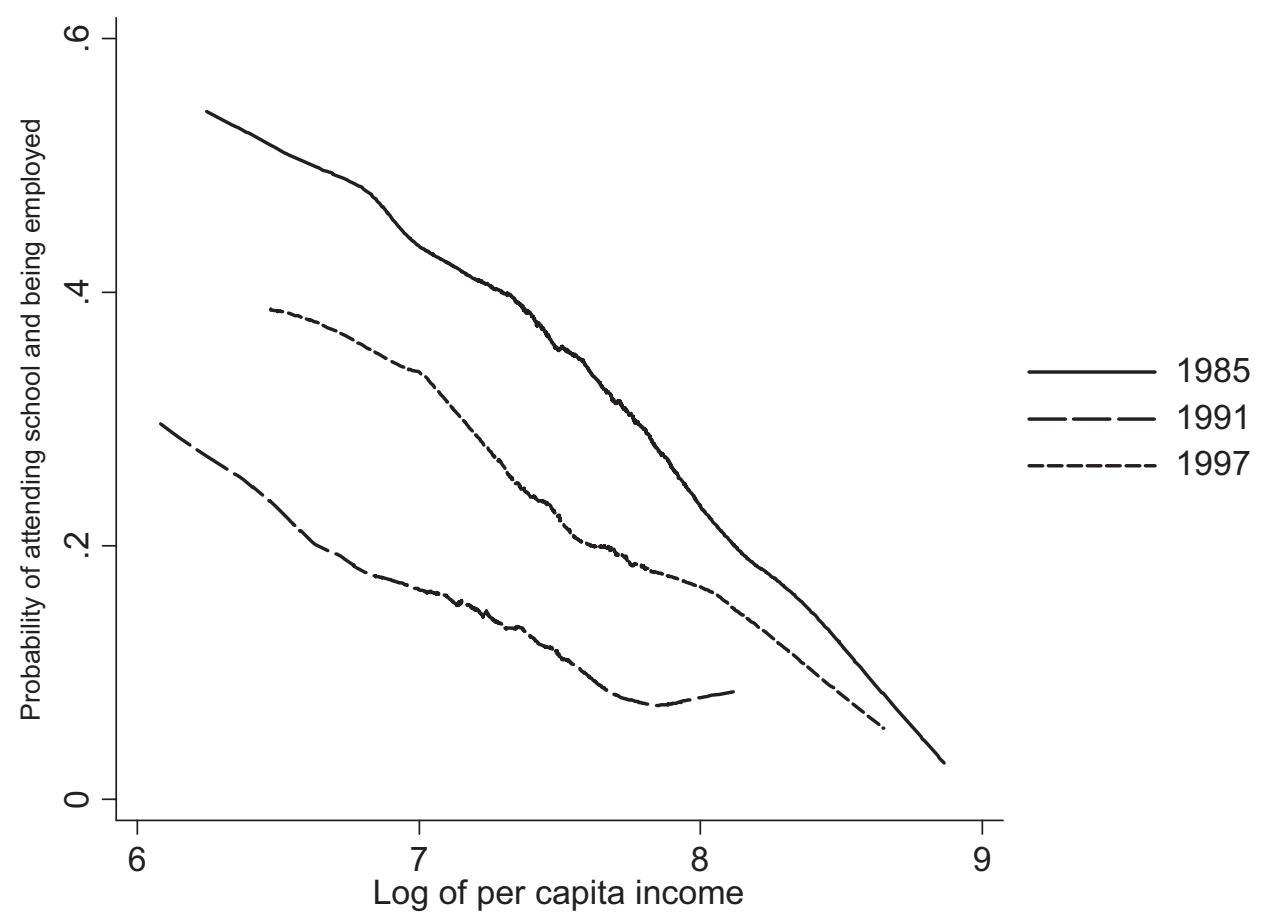

Source: Author's calculations based on the LSMS surveys for 1985/86, 1991, and 1997.

\section{Educational Attainment}

Two sets of oLs regressions for the mean number of grades completed are presented in table 7. In the upper panel, every year of crisis exposure is constrained to have the same effect, whereas the effect is allowed to vary by year in the lower panel. The results for the continuous exposure variable suggest that every year of exposure to the crisis is associated with a 0.04 to 0.05 increase in the number of grades completed. That is, children who were of school age for the entire 1988-92 period would have completed about one-quarter more grades than those who were not of school age during the crisis. Because grades completed are measured in whole integers only, one way of interpreting this coefficient is that one out of every four or five children exposed to the entire crisis period has completed one more grade compared with children who were not exposed to the crisis.

The dummy variable specifications in the lower panel of table 7 provide some evidence that school attainment does not increase proportionately with crisis exposure. A "low" amount of crisis exposure (1 to 2 years) appears to have no effect on the number of grades completed, whereas a "high" amount of crisis exposure ( 3 to 5 years) increases grade completion by about 0.2 years. This could 
Table 7. Average Number of Grades Completed, Ages 6-17

\begin{tabular}{lccc}
\hline & Specification $(1)^{\mathrm{a}}$ & Specification $(2)^{\mathrm{b}}$ & ${\text { Specification }(3)^{\mathrm{c}}}^{\circ}$ \\
\hline Years of crisis exposure & $0.050^{* * *}$ & $0.044^{* *}$ & $0.043^{* *}$ \\
$R^{2}$ & 0.81 & 0.86 & 0.87 \\
Number of observations & 8,646 & 6,203 & 4,917 \\
Crisis exposure $=0$ & - & - & - \\
Crisis exposure $=1$ & 0.008 & 0.057 & 0.035 \\
Crisis exposure $=2$ & -0.011 & 0.052 & 0.089 \\
Crisis exposure $=3$ & $0.204^{* *}$ & $0.165^{*}$ & $0.173^{*}$ \\
Crisis exposure $=4$ & $0.184^{* *}$ & $0.236^{* *}$ & $0.234^{* *}$ \\
Crisis exposure $=5$ & $0.224^{* *}$ & $0.204^{*}$ & $0.199^{*}$ \\
$R^{2}$ & 0.82 & 0.86 & 0.87 \\
Number of observations & 8,646 & 6,203 & 4,917 \\
\hline
\end{tabular}

Note: All specifications include dummy variables for the 1985/86 and 1997 survey years. Standard errors are corrected for heteroscedasticity and clustering.

"Significant at the 10 percent level.

**Significant at the 5 percent level.

$\because *$ Significant at the 1 percent level.

${ }^{a}$ Includes geographic stratum and gender controls and a vector of age dummy variables.

${ }^{\mathrm{b}}$ Supplements specification 1 with variables for the education of both parents (separately), household size, the number of household members under age 3 , ages $3-5$, ages $6-8$, ages $9-11$, ages $12-14$, and ages $15-17$.

'This fixed effects specification limits the sample to households living in districts that were included in the sample in 1985/86, 1991, and 1997, and includes the variables in specification (2), as well as a dummy variable for each district.

Source: Author's calculations based on LSMS surveys for 1985/86, 1991, and 1997.

mean that it takes some time for children or their parents to adjust their schooling and employment decisions to a crisis. Too much should not be made of these more nuanced results, however. F-tests on the additional coefficients fail to reject the null that these dummy variable specifications do not represent a significant improvement in fit over the more parsimonious specifications in which crisis exposure enters the regression linearly.

\section{Interpretation of Results}

Macroeconomic crises can affect the total amount of schooling chosen, the timing of schooling, and the extent to which schooling is combined with work. The 1988-92 crisis in Peru appears to have reduced access to credit, which should have led to a reduction in human capital investment. The effect of the crisis on the marginal benefits from education is unclear in theory. Only if the crisis had been perceived as persistent and as disproportionately reducing the earnings and employment prospects of low-skilled workers could changes in the marginal benefit of schooling explain the observed patterns in enrollment and grade attainment. Yet the crisis does not seem to have had a disproportionate effect on less educated workers. Comparisons based on the 1985/86, 1991, and 1997 surveys suggest that incomes fell substantially for all categories of 
households, whatever the amount of schooling of the household head. ${ }^{15}$ Moreover, using data from annual labor force surveys conducted in Lima, Saavedra (1998) and Saavedra and Maruyama (1998) show that the rate of return to education estimated from a standard Mincerian regression fell noticeably during the crisis (from 0.11 in 1987 to 0.08 in 1991) and rose steadily thereafter (to about 0.13 in 1995). It therefore seems unlikely that changes in access to credit or in the marginal benefit to education can explain the patterns in school attendance and grade completion in Peru.

The crisis appears to have affected education outcomes through a substantial reduction in forgone income-the opportunity cost of attending school. Real wages in urban areas dropped precipitously during the crisis. Saavedra (1998) estimates that the mean real monthly wage for informal sector workers in Lima fell from about 600 soles in 1987 to 200 soles in 1991, before recovering partially to about 400 soles in 1997. Formal sector workers suffered even more staggering declines, with real monthly wages plunging from 1,200 soles to 200 soles between 1987 and 1991 and recovering to 800 soles by 1997 . These results suggest that there was a very steep decline in the opportunity cost of schooling in Lima during the crisis.

Children who hold jobs in Peru in noncrisis years may have been less willing and able to combine school and work during the 1988-92 crisis. The extent to which a reduction in child employment frees up time for schooling or for child leisure is an unresolved issue in the literature on child labor. The three Peru Lsms surveys have no time allocation data and so cannot be used to answer this question conclusively. But the results presented here are consistent with some substitution between employment and schooling. During the 1988-92 crisis children in Peru were less likely to combine school with work, and they were more likely to make adequate grade progress. Arguably, children who were not working could expend more effort in school.

Two potential complications for interpreting the results are possible changes in public expenditures on education and changes in migration patterns, specifically migration from rural to urban areas. An increase in public expenditures on education during a crisis could reduce the marginal cost of education (for example, if the increased expenditure takes the form of scholarships) or increase the marginal benefits (for example, if the increased expenditure improves the quality of education).

15. Glewwe and Hall (1998) report results based on a panel of households in Lima only included in the 1985/86 LSMs survey and in a follow-up survey in 1990. These results suggest that households in which the head had more schooling suffered smaller income losses. The analysis here finds no clear pattern. A simple tabulation of income by the education of the household head shows a greater drop in mean income in households with heads with some secondary education ( -41 percent) than in households with heads with a primary education or less $(-27$ percent), or some tertiary education $(-25$ percent). The recovery in incomes between 1991 and 1997, by contrast, clearly favored households with more schooling. Incomes between 1991 and 1997 increased by 2 percent for households with heads with a primary education or less, 19 percent for households with some secondary education, and 76 percent for households with some tertiary education. 
Figure 5. Recurrent and Capital Public Expenditures on Education, 1980-97 (constant 1997 soles)

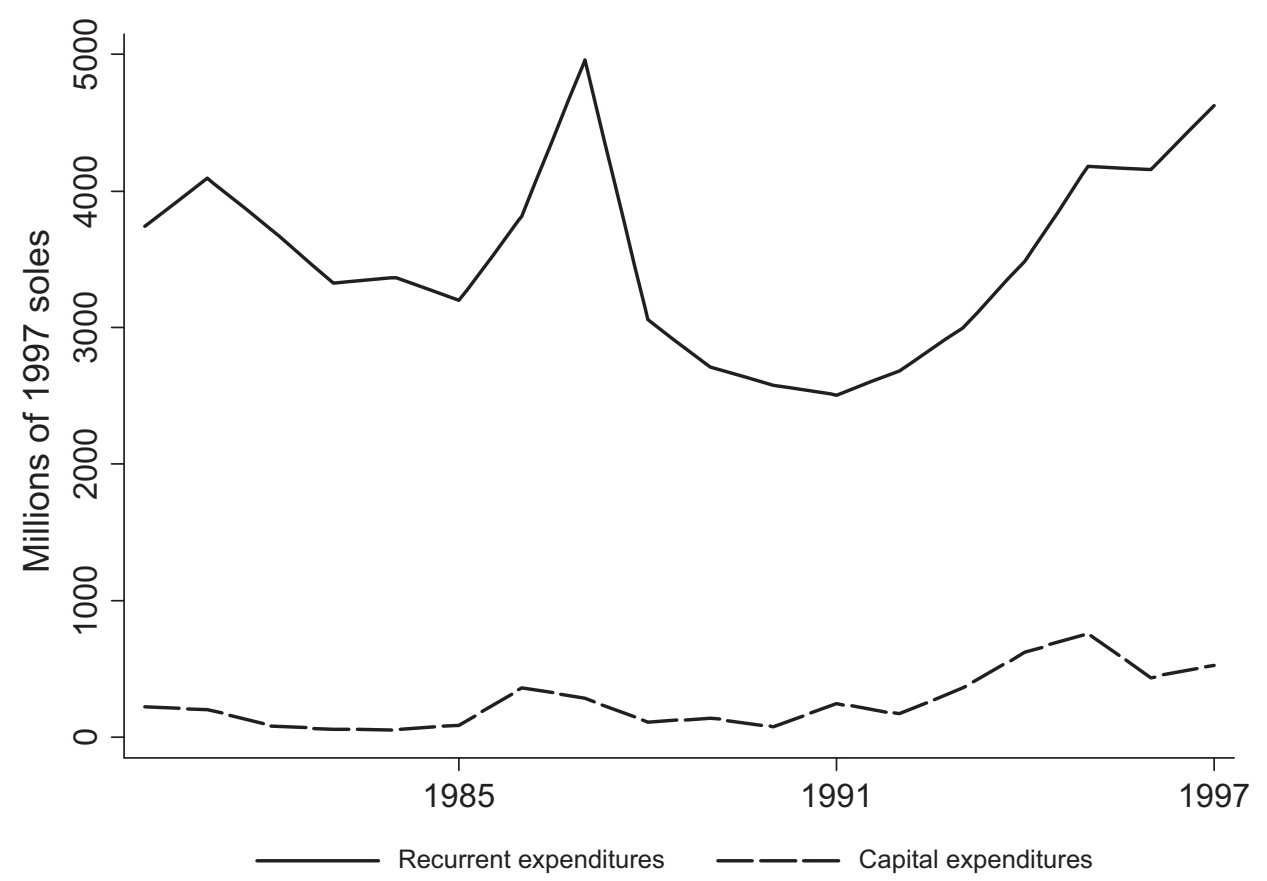

Source: World Bank staff calculations based on data from the Peruvian Ministry of Economics and Finance.

The García government had no program for keeping children in school during the crisis. Indeed, public expenditures on education followed roughly the same pattern as per capita GDP — rising sharply between 1985/86 and 1987, dropping equally sharply between 1987 and 1991, and increasing steadily thereafter (figure 5). If anything, the constant attendance patterns and the improvements in age-specific grade completion during the crisis took place despite the changes in public expenditures on education. Moreover, it is unlikely that households compensated for changes in public expenditures by increasing private expenditures on education between 1985/86 and 1991 and reducing them thereafter. At best, households may have been able to protect these expenditures somewhat in the context of dramatic cutbacks in overall household income. ${ }^{16}$ Also, a decree passed between the 1995 and 1996 school years called for automatically promoting to second grade all children who completed first grade. This could bias downward the estimates for the impact of the crisis on grade attainment reported in this article. By construction, all

16. Data from countries affected by the 1998 East Asian crisis, for example, show a varied picture. In Indonesia private expenditures on education fell both in absolute terms and as a share of total household expenditures, whereas in the Republic of Korea private expenditures on education fell by less than overall household spending (World Bank 2000, p. 121). 
first-graders 8 years old or younger in 1995, who stood to benefit from the automatic promotion policy, are defined as unexposed to the crisis because they would be 10 years old or younger in 1997.

Migration is a concern because the sample is limited to Lima and the urban areas of the coast and sierra. In Peru migration has traditionally been from rural to urban areas, although there appears to have been an important migration from urban to rural areas in the mid-1990s. This reverse migration was a response to the improved security in the countryside as a result of the weakening of the Shining Path and Túpac Amaru Revolutionary Movement after 1992 and of government policies to encourage resettlement of abandoned rural areas. Lower mean incomes and lower adult education levels in rural areas suggest lower underlying propensities to attend school and complete grades among migrants than among the sedentary population. Rural to urban migration could thus diminish the propensity to attend school and make satisfactory grade progress of the 1991 sample relative to the 1985/86 sample, whereas urban to rural migration could diminish this propensity in the 1991 sample relative to the 1997 sample. To the extent that this is the case, the estimates presented here of the effect of the crisis would be downwardly biased. In the absence of migration the estimated coefficients on the measures of crisis exposure would have been even larger.

\section{Conclusion}

This article examines the impact of the profound 1988-92 macroeconomic crisis in Peru on patterns of accumulation of human capital. The main finding is that households, including poor households, were very reluctant to make cutbacks in key human capital investments. There is no evidence of a drop in school attendance. Children exposed to the crisis were less likely to combine work with school and had completed more grades than children unexposed to the crisis.

The results suggest that macroeconomic crises do not always slow human capital accumulation in developing economies. Of course, crises have serious consequences for household welfare. Income falls, and consumption may fall if households cannot smooth out the income shock. The health status of children may deteriorate. In Peru, Paxson and Schady (2004) find that the 1988-92 crisis led to a sharp increase in infant mortality and a deterioration in the nutritional status of children. The quality of education may suffer because of the cutbacks in private and public expenditure.

The main message of these results is not therefore that there are no social costs of macroeconomic crises. Rather, the policy implications are first, given the variation in impacts reported in the literature, further research is needed to understand why macroeconomic crises lead to a slowdown in human capital accumulation in some countries but not in others. Second, in some middleincome countries, where aggregate reductions in incomes do not appear to lead to worse schooling outcomes, it may be more important to put in place policies to protect consumption and health rather than policies to reduce school dropouts during a crisis. 


\section{ApPENDix}

Table A-1. Exposure to Economic Crisis by Age and Survey Year

\begin{tabular}{|c|c|c|}
\hline Age (years) & Survey year & Exposure (number of years) \\
\hline 6 & $1985 / 86$ & 0 \\
\hline 7 & $1985 / 86$ & 0 \\
\hline 8 & $1985 / 86$ & 0 \\
\hline 9 & $1985 / 86$ & 0 \\
\hline 10 & $1985 / 86$ & 0 \\
\hline 11 & $1985 / 86$ & 0 \\
\hline 12 & $1985 / 86$ & 0 \\
\hline 13 & $1985 / 86$ & 0 \\
\hline 14 & $1985 / 86$ & 0 \\
\hline 15 & $1985 / 86$ & 0 \\
\hline 16 & $1985 / 86$ & 0 \\
\hline 17 & $1985 / 86$ & 0 \\
\hline 6 & 1991 & 1 \\
\hline 7 & 1991 & 2 \\
\hline 8 & 1991 & 3 \\
\hline 9 & 1991 & 4 \\
\hline 10 & 1991 & 5 \\
\hline 11 & 1991 & 5 \\
\hline 12 & 1991 & 5 \\
\hline 13 & 1991 & 5 \\
\hline 14 & 1991 & 5 \\
\hline 15 & 1991 & 5 \\
\hline 16 & 1991 & 5 \\
\hline 17 & 1991 & 5 \\
\hline 6 & 1997 & 0 \\
\hline 7 & 1997 & 0 \\
\hline 8 & 1997 & 0 \\
\hline 9 & 1997 & 0 \\
\hline 10 & 1997 & 0 \\
\hline 11 & 1997 & 1 \\
\hline 12 & 1997 & 2 \\
\hline 13 & 1997 & 3 \\
\hline 14 & 1997 & 4 \\
\hline 15 & 1997 & 5 \\
\hline 16 & 1997 & 5 \\
\hline 17 & 1997 & 5 \\
\hline
\end{tabular}

Source: Author's calculations based on LSMS surveys for 1985/86, 1991, and 1997.

\section{REFERENCES}

Becker, Gary. 1964. Human Capital: A Theoretical and Empirical Analysis with Special Reference to Education. Chicago: University of Chicago Press.

Behrman, Jere R., Suzanne Duryea, and Miguel Szekely. 2000. "Schooling Investments and Aggregate Conditions: A Household-Survey-Based Approach for Latin America and the Caribbean.” Working Paper, Inter-American Development Bank, Washington, D.C. 
Deaton, Angus. 2003. "Measuring Poverty in a Growing World (or Measuring Growth in a Poor World).” NBER Working Paper 9822. Cambrige, Mass.: National Bureau of Economic Research.

De Ferranti, David, Guillermo E. Perry, Indermit S. Gill, and Luis Servén. 2000. Securing Our Future in a Global Economy. Washington, D.C.: World Bank.

España, Sergio, Suhas Parandekar, and Maria Paula Savanti. 2002. "El impacto de la crisis en el proceso educativo en Argentina.” Working Paper, World Bank, Washington, D.C.

Filmer, Deon. 1999. Educational Attainment and Enrollment Profiles: A Resource Book Based on an Analysis of Demographic and Health Surveys Data. Washington, D.C.: World Bank.

Flug, Karnit, Antonio Spilimbergo, and Erik Wachtenheim. 1998. "Investments in Education: Do Economic Volatility and Credit Constraints Matter?" Journal of Development Economics 55(2):465-81.

Glewwe, Paul, and Gillette Hall. 1994. "Poverty, Inequality and Living Standards during Unorthodox Adjustment: The Case of Peru, 1985-1990." Economic Development and Cultural Change 42(4):689-717.

1998. "Are Some Groups More Vulnerable to Macroeconomic Shocks than Others? Hypothesis Tests Based on Panel Data from Peru.” Journal of Development Economics 56(1):181-206.

Goldin, Claudia. 1999. "Egalitarianism and the Returns to Education during the Great Transformation of American Education.” Journal of Political Economy 107(6):S65-S94.

Jacoby, Hanan G. 1994. "Borrowing Constraints and Progress through School: Evidence from Peru." Review of Economics and Statistics 76(1):151-60.

Jacoby, Hanan G., and Emmanuel Skoufias. 1997. "Risk, Financial Markets, and Human Capital in a Developing Country.” Review of Economic Studies 64(3):311-35.

Jensen, Robert. 2000. "Agricultural Volatility and Investments in Children.” American Economic Review Papers and Proceedings 90(2):399-404.

Paxson, Christina, and Norbert R. Schady. 2002. "The Allocation and Impact of Social Funds: Spending on School Infrastructure in Peru." World Bank Economic Review 16(2):297-319.

2004. "Child Health and the 1988-92 Economic Crisis in Peru." Policy Research Working Paper 3260. World Bank, Washington, D.C.

Ravallion, Martin. 2003. "Measuring Aggregate Welfare in Developing Countries: How Well Do National Accounts and Surveys Agree?” Review of Economics and Statistics 85(3):645-52.

Rosen, Sherwin. 1977. "Human Capital: A Survey of Empirical Research." In Ronald Ehrenberg, ed., Research in Labor Economics. Greenwich, Conn.: JAI Press.

Saavedra, Jaime. 1998. "Crisis real o de expectativas? El empleo en el Perú antes y después de las reformas estructurales.” GRADE Working Paper 25. Grupo de Análisis para el Desarrollo, Lima.

Saavedra, Jaime, and Eduardo Maruyama. 1998. "Los retornos a la educación y a la experiencia en el Perú: 1985-1997.” In Richard Webb and Moisés Ventocilla, eds., Pobreza y economía social: Análisis de una encuesta ENNIV-1997. Lima: Instituto Cuánto.

Schady, Norbert R. 2001. "Convexity and Sheepskin Effects in the Human Capital Earnings Function: Recent Evidence for Filipino Men.” Policy Research Working Paper 2566. World Bank, Washington, D.C.

2002. "Picking the Poor: Indicators for Geographic Targeting in Peru." Review of Income and Wealth 48(3):417-33.

Strauss, John, Kathleen Beegle, Agus Dwiyanto, Yulia Herawati, Daan Pattinasarany, Elan Satriawan, Bondan Sikoki, Sukamdi, and Firman Witoelar. 2004. Indonesian Living Standards before and after the Financial Crisis: Evidence from the Indonesia Family Life Survey. Santa Monica, Calif.: RAND.

Thomas, Duncan, Kathleen Beegle, Elizabeth Frankenberg, Bondan Sikoki, John Strauss, and Graciela Teruel. 2004. "Education in a Crisis." Journal of Development Economics 74(1):53-85.

Willis, Robert. 1986. "Wage Determinants: A Survey and Reinterpretation of Human Capital Earnings Functions." In Orley Ashenfelter and Richard Layard, eds., Handbook of Labor Economics. New York: North Holland. 
World Bank. 1995. "Peru: Country Assistance Strategy." Washington, D.C.

- 1999a. Peru Education at a Crossroads: Challenges and Opportunities for the 21st Century. Washington, D.C.

-1999b. Poverty and Social Developments in Peru, 1994-1997. Washington, D.C.

2000. East Asia: Recovery and Beyond. Washington, D.C.

- 2001. World Development Report 2000/2001: Attacking Poverty. New York: Oxford University Press. 